\title{
A new porphyrin sensitizer with phenolic binding group for high efficiency dye-sensitized solar cells
}

\author{
Liguo JiN ${ }^{1}$, HongJie WANG ${ }^{1}$, SHUO WANG ${ }^{1}$, LIPING WEN $^{4}$, JIN ZHAI $^{* 2}$, TIANXIN WEI ${ }^{3}$ \\ ${ }^{1}$ The School of Material Science \& Engineering, Harbin University of Science and Technology, Harbin 150040, P. R. China \\ ${ }^{2}$ Key Laboratory of Bio-Inspired Smart Interfacial Science and Technology of Ministry of Education, School of Chemistry \\ and Environment, Beihang University, Beijing 100191, P. R. China \\ ${ }^{3}$ Institute for Chemical Physics, Beijing Institute of Technology, Beijing, 100081, P. R. China \\ ${ }^{4}$ Institute of Chemistry, Chinese Academy of Sciences, Beijing 100190, P. R. China
}

\begin{abstract}
A novel zinc porphyrin (5,10,15-tri-dodecoxyphenyl-20-(4-hydroxyphenyl-azo-benzenyl)-porphyrinatozinc (tdhab-ZnP)) with benzenyl-azo-phenolic group, able to adsorb on the nanocrystalline- $\mathrm{TiO}_{2}$ film, has been synthesized. We constructed a dye-sensitized solar cell based on the nanocrystalline- $\mathrm{TiO}_{2}$ hierarchical structure film, with a power conversion efficiency of $4.15 \%$ and a high current density of $14 \mathrm{~mA} / \mathrm{cm}^{2}$ under AM 1.5 irradiation. UV-Vis absorption spectra measurements indicated that the tdhab-ZnP molecules formed a charge transfer complex with $\mathrm{TiO}_{2}$ nanoparticles (NPs) through the phenolic group. Cyclic voltammetry measurement showed that the charge separation resulting from the tdhab-ZnP excited singlet state to the conduction band $(\mathrm{CB})$ of $\mathrm{TiO}_{2}$ and charge shifting from the $\mathrm{I}^{-} / \mathrm{I}_{3}^{-}$couple to the porphyrin radical cation were thermodynamically feasible.
\end{abstract}

Keywords: dye-sensitized solar cell; porphyrin; nanocrystalline-TiO

(C) Wroclaw University of Technology.

\section{Introduction}

Dye-sensitized solar cells (DSSCs) based on nanocrystalline semiconductors have received considerable attention because of their relatively low cost and high efficiency for the photo-electrical conversion of solar energy [1, 2]. Sensitizers, as a key components in DSSCs, exert significant influence on the photovoltaic performance. Ruthenium (II) polypyridyl and its derivatives have so far been regarded as the best sensitizing dyes for solar energy conversion due to their strong visible absorption bands, long-lived excited state and excellent photochemical stability. DSSCs based on Ru dyes can produce solar energy to electricity conversion efficiency $(\eta)$ of up to $11 \%$ under AM 1.5 irradiation [3-5]. However, these complexes, which show poor red/near-infrared (NIR) light absorption, are unsatisfactory and cause environmental problems. In view of the excellent photochemical and

*E-mail: zhaijin@buaa.edu.cn electrochemical properties of porphyrins and their low cost of production as well as broad absorption in the visible and NIR region, many researchers have taken keen interest in solar cells based on porphyrins dye-sensitized nanocrystalline $\mathrm{TiO}_{2}[6,7]$.

In this regard, in the solar cells developed from porphyrin dyes, majority of the anchoring groups are carboxylates $[8,9]$ and sometimes phosphonates [10] and sulfonates [11]. However, there are some disadvantages in using carboxylate functionality as anchoring groups though they show outstanding photoelectric properties. The ground-state $\mathrm{pK}_{a}$ values of the carboxylates are too low to ensure strong binding [12]. In addition, in the presence of water, slow desorption of the photosensitizers can occur, which may limit the long-term stability of the cell. The aggregation of porphyrin dye, which causes intermolecular energy transfer, is also considered to be one of the factors decreasing photovoltaic performance of DSSCs based on organic dyes [13]. Das et al. [14] have observed that 
catecholate binding is stronger than any other type of binding, which can form a charge transfer (CT) complex with $\mathrm{TiO}_{2}$ NPs through the catechol moiety of porphyrins by a five-membered ring. Campbell et al. $[15,16]$ have demonstrated that the presence of a conjugated linkage between porphyrin and a binding group significantly enhanced solar cell performance. Recently, it was found that an efficient retardation of the charge recombination process and a significant improvement of device performance could be achieved by using organic dyes with lateral alkyl chains $[17,18]$. With the long alkyl chains, the lifetime of electrons can be increased by preventing the acceptors (i.e. $\mathrm{I}_{3}^{-}$ion) to approach the $\mathrm{TiO}_{2}$ surface and/or by reducing the reorganization energy of the dye, resulting in the desired condition for the kinetic competition for reduction of the dye cations [19]. The aggregation of dye molecules would also be suppressed by the steric hindrance due to the long alkyl chains. Up to now, porphyrin sensitizers with carboxylate binding groups have provided a higher photoelectric conversion efficiency than that of other binding groups. In 2010 and 2011, Michael Grätzel's group reported the DSSCs with the novel porphyrin sensitizers that gave an overall conversion efficiency of $11 \%$ and $12 \%$, which were the best for porphyrinbased sensitizers [20, 21].

Taking these points into account, further development of strategic molecular design of a porphyrin dye is required to achieve higher lightelectricity conversion efficiency values. Herein, our design toward the high photovoltaic performance of porphyrin-dye sensitized solar cells is based on the interfacial engineering of a dye adsorbed on $\mathrm{TiO}_{2}$ surface, which can be controlled by the structural modification of the porphyrin molecule to diminish the charge recombination between the electrons and acceptors, that is, to prevent the recombination of dye cation and $\mathrm{I}_{3}^{-}$ions, and the aggregation of the dye molecules.

A $\pi$-elongated porphyrin with benzenyl-azophenol was synthesized with phenolic group acting as the bonding group (Fig. 1). The $\pi$-elongated porphyrin with azobenzenyl group should benefit from the fast electron injection into the $\mathrm{CB}$ of the semiconductor and slow charge recombination between the injected electron and the sibling dye cation, while introduction of alkyl chain groups $\left(\mathrm{C}_{12} \mathrm{H}_{25}-\right)$ is expected to enhance the distance between the core of porphyrins and $\mathrm{I}_{3}^{-}$ions so that to decrease the dark current, leading to the improvement of the photovoltaic properties.

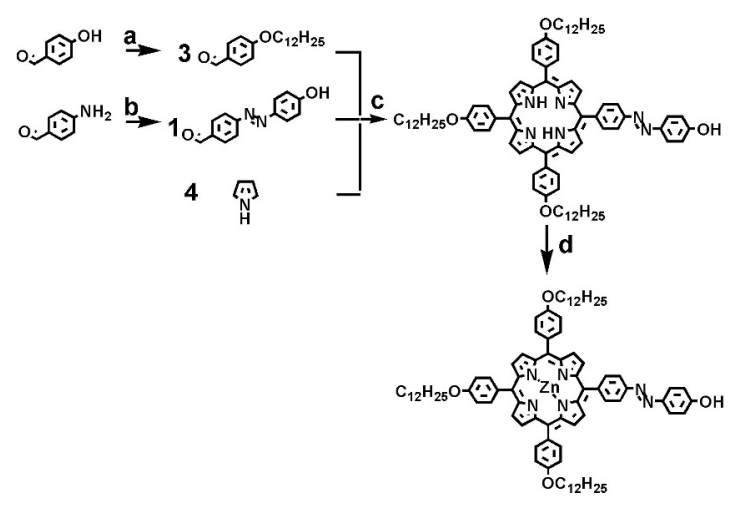

Fig. 1. Reagents and conditions: (a) acetone, $\mathrm{BrC}_{12} \mathrm{H}_{25}$, $\mathrm{K}_{2} \mathrm{CO}_{3}$, reflux, $\mathrm{N}_{2}$, RT (10 h); (b) $\mathrm{HCl}, \mathrm{NaNO}_{2}$, 0 to $5{ }^{\circ} \mathrm{C}$; phenol, $0{ }^{\circ} \mathrm{C}$, RT (2 h); (c) $\mathrm{CHCl}_{3}$, $\mathrm{BF}_{3} \mathrm{OEt}_{2}$, RT (1 h); DDQ; Et $3 \mathrm{~N}$, RT (1 h); (d) $\mathrm{Zn}\left(\mathrm{CH}_{3} \mathrm{COO}\right)_{2}, \mathrm{CH}_{3} \mathrm{OH} 70{ }^{\circ} \mathrm{C}$, RT (30 min).

\section{Experimental}

\subsection{Synthesis and characterization}

The synthetic route to prepare the porphyrin antenna molecule of (5,10,15-tri-dodecoxyphenyl20 - (4 - hydroxyphenyl - azo- benzenyl) - porphyrin (tdhab- $\mathrm{H}_{2} \mathrm{P}$ ) is shown in Fig. $1 . \mathrm{H}_{2} \mathrm{P}$ was prepared by the reaction of $\mathrm{p}$-dodecoxybenzaldehyde, aldehyde-azo- $\mathrm{Ph}-\mathrm{OH}$ and pyrrole in chloroform under nitrogen atmosphere, at room temperature, under stirring. Five minutes later, boron trifluoride etherate $\left(\mathrm{BF}_{3} \mathrm{OEt}_{2}\right)$ was added into the above mixture. After an hour, the proper 2,3-dichloro5,6-dicyano-1,4-benzoquinone (DDQ) was added to the flask and reacted for 1 hour. Triethylamine $\left(\mathrm{Et}_{3} \mathrm{~N}\right)$ was then used to neutralize the reaction. The mixture solvent was removed and the product was purified using column chromatography (eluent dichloromethane), yielding a purple solid. ${ }^{1} \mathrm{H}$ NMR $\left(\mathrm{CDCl}_{3}, 400 \mathrm{MHz}\right): \delta=8.89$ (m, broad, $8 \mathrm{H}, \beta$-pyrrole), 8.35 (d, $2 \mathrm{H}, \mathrm{CH}$ ortho-Ph-OH, $J=$ $7.6 \mathrm{~Hz}), 8.26$ (d, 2H, CHmeta-Ph-OH, $J=7.6 \mathrm{~Hz}$ ), 
8.11 (d, 6H, CHortho- $\mathrm{Ph}-\mathrm{OC}_{12} \mathrm{H}_{25}, J=8.4 \mathrm{~Hz}$ ), $8.00(\mathrm{~d}, 2 \mathrm{H}, \mathrm{CH}$ meta-Ph-N=N, $J=8.3 \mathrm{~Hz}$ ), $7.26\left(\mathrm{~d}, 6 \mathrm{H}, \mathrm{CH}\right.$ meta- $\mathrm{Ph}-\mathrm{OC}_{12} \mathrm{H}_{25}, J=7.2 \mathrm{~Hz}$ ), $6.89(\mathrm{~d}, 2 \mathrm{H}, \mathrm{CH}$ ortho- $\mathrm{Ph}-\mathrm{N}=\mathrm{N}, J=8.3 \mathrm{~Hz}$ ), $4.28\left(\mathrm{t}, 6 \mathrm{H}, \mathrm{OCH}_{2} \mathrm{C}_{11} \mathrm{H}_{23}, J=6.2 \mathrm{~Hz}\right.$ ), 2.33 (s, $1 \mathrm{H}, \mathrm{Ph}-\mathrm{OH}), 1.97\left(\mathrm{~m}, 6 \mathrm{H}, \mathrm{OCH}_{2} \mathrm{CH}_{2} \mathrm{C}_{10} \mathrm{H}_{21}\right)$, $1.81\left(\mathrm{~m}, \quad 6 \mathrm{H}, \quad \mathrm{OC}_{2} \mathrm{H}_{4} \mathrm{CH}_{2} \mathrm{C}_{9} \mathrm{H}_{19}\right), 1.62 \quad(\mathrm{~m}$, $\left.6 \mathrm{H}, \quad \mathrm{OC}_{3} \mathrm{H}_{6} \mathrm{CH}_{2} \mathrm{C}_{8} \mathrm{H}_{17}\right), \quad 1.39 \quad(\mathrm{~m}, \quad 42 \mathrm{H}$, $\left.\mathrm{OC}_{3} \mathrm{H}_{6} \mathrm{C}_{7} \mathrm{H}_{14} \mathrm{CH}_{3}\right), 0.90$ (m, 9H, OC $\left.{ }_{11} \mathrm{H}_{22} \mathrm{CH}_{3}\right)$, -2.72 (s, broad, 2H, NH-porphyrin). MS (MALDI-TOF): $\mathrm{m} / \mathrm{z}$ 1287.7, calculated for $\mathrm{C}_{86} \mathrm{H}_{106} \mathrm{~N}_{6} \mathrm{O}_{4}: 1286.8$.

Then tdhab-ZnP was also prepared from $\mathrm{H}_{2} \mathrm{P}$ by $\mathrm{Zn}$ (II)-metallation (Fig. 1). ${ }^{1} \mathrm{H} \mathrm{NMR}\left(\mathrm{CDCl}_{3}\right.$, $400 \mathrm{MHz}$ ): $\delta=8.88$ (m, broad, $8 \mathrm{H}, \beta$-pyrrole), 8.35 (d, 2H, CHortho-Ph-OH, $J=7.6 \mathrm{~Hz}$ ), 8.28 (d, 2H, CHmeta-Ph-OH, $J=7.6 \mathrm{~Hz}$ ), 8.11 (d, $6 \mathrm{H}, \mathrm{CH}$ ortho- $\left.\mathrm{Ph}-\mathrm{OC}_{12} \mathrm{H}_{25}, J=7.2 \mathrm{~Hz}\right), 8.00$ (d, 2H, CHmeta-Ph-N=N, J $=8.3 \mathrm{~Hz}$ ), 7.26 (d, 6H, CHmeta-Ph- $\mathrm{OC}_{12} \mathrm{H}_{25}, J=7.2 \mathrm{~Hz}$ ), 7.01 (d, 2H, CHortho- $\mathrm{Ph}-\mathrm{N}=\mathrm{N}, J=8.3 \mathrm{~Hz}$ ), $4.26\left(\mathrm{t}, 6 \mathrm{H}, \mathrm{OCH}_{2} \mathrm{C}_{11} \mathrm{H}_{23}, J=6.2 \mathrm{~Hz}\right), 2.31$ (s, $1 \mathrm{H}, \mathrm{Ph}-\mathrm{OH}), 2.00\left(\mathrm{~m}, 6 \mathrm{H}, \mathrm{OCH}_{2} \mathrm{CH}_{2} \mathrm{C}_{10} \mathrm{H}_{21}\right)$, $1.81\left(\mathrm{~m}, \quad 6 \mathrm{H}, \quad \mathrm{OC}_{2} \mathrm{H}_{4} \mathrm{CH}_{2} \mathrm{C}_{9} \mathrm{H}_{19}\right), 1.61 \quad(\mathrm{~m}$, $\left.6 \mathrm{H}, \quad \mathrm{OC}_{3} \mathrm{H}_{6} \mathrm{CH}_{2} \mathrm{C}_{8} \mathrm{H}_{17}\right), \quad 1.30 \quad(\mathrm{~m}, \quad 42 \mathrm{H}$, $\left.\mathrm{OC}_{3} \mathrm{H}_{6} \mathrm{C}_{7} \mathrm{H}_{14} \mathrm{CH}_{3}\right), 0.89$ (m, 9H, OC $\left.{ }_{11} \mathrm{H}_{22} \mathrm{CH}_{3}\right)$. MS (MALDI-TOF): $\mathrm{m} / \mathrm{z}$ 1349.4, calculated for $\mathrm{C}_{86} \mathrm{H}_{104} \mathrm{~N}_{6} \mathrm{O}_{4} \mathrm{Zn}: 1348.7$.

\subsection{Photoelectrochemical solar cells}

DSSCs were fabricated as previously described in $[22,23]$. Nanocrystalline- $\mathrm{TiO}_{2}$ hierarchical structure film electrode was fabricated by the electro-hydrodynamic technique (EHD). The $\mathrm{TiO}_{2}$ colloidal suspension was composed of ethanol (5 mL), polyvinyl alcohol (PVA, $\mathrm{MW}=22,000)$ water solution $(1 \mathrm{~g}, 33 \mathrm{wt} . \%)$, titanium sol $\left(6.6 \mathrm{~mL}, 0.1 \mathrm{~g} \cdot \mathrm{L}^{-1}\right)$. Anatase $\mathrm{TiO}_{2}$ nanoparticles were hydrothermally synthesized according to [24]. The suspension was sprayed onto the conductive fluorine-doped tin oxide (FTO) glass slides (Nippon, $14 \Omega / \square$ ) with a buffer layer (the preparation method, of which was described in [22]). Then, the $\mathrm{TiO}_{2}$ composite film was annealed at $450{ }^{\circ} \mathrm{C}$ for 1 hour in air, resulting in a $6 \mu \mathrm{m}$ thick film. The as-prepared electrode was put into $0.2 \mathrm{M} \mathrm{TiCl}_{4}$ aqueous solution overnight at room temperature and annealed again for $30 \mathrm{~min}$ at $450{ }^{\circ} \mathrm{C}$ in air. The sensitizer was adsorbed onto this film by dipping it into a $0.3 \mathrm{mM}$ tdhab-ZnP solution dissolved in $\mathrm{CH}_{2} \mathrm{Cl}_{2}$ and leaving it there overnight. After completion of the dye coating, the electrode was rinsed with dry $\mathrm{CH}_{2} \mathrm{Cl}_{2}$ and dried in a flow of nitrogen. The DSSC was composed of a sensitized photo-anode, a platinum counter electrode, and an electrolyte. Liquid electrolyte was composed of $0.1 \mathrm{M}$ LiI (Aldrich), $0.05 \mathrm{M}$ iodine (Inland), $0.45 \mathrm{M}$ $\mathrm{N}$-methyl-benzimidazole (NMBI) (Aldrich) and $0.6 \mathrm{M}$ 1-propyl-3-methylimidazolium iodide (MPII) (Shanghai Cheng Jie Chemical Co. Ltd.) in acetonitrile.

\subsection{Measurements}

The surface morphology and thickness of these porous films were determined by scanning electron microscope (SEM, JEOL, JSM-6700F). The I-V characteristics of the devices were measured using an electrochemical analyzer (CHI630B, Chenhua Instruments Co., Shanghai) under illumination of different simulated solar light intensities (CMH-250, Aodite Photoelectronic Technology Ltd., Beijing) at room temperature. The incident photon-to-current efficiency (IPCE) curve of the DSSCs was measured by illumination with mono-chromatic light, which was obtained by passing light through a series of light filters with different wavelengths. The active area of the solar cell was $0.20 \mathrm{~cm}^{2}$. All of the experimental values were given as an average from four independent measurements. The UV-Vis spectra were measured with a spectrophotometer (U3010, HITACHI). Cyclic voltammetric experiments were performed in $0.03 \mathrm{mM}$ tdhab-ZnP in $\mathrm{CH}_{2} \mathrm{Cl}_{2}$ solution at a scan rate of $20 \mathrm{mV} / \mathrm{s}$ using $0.1 \mathrm{M}$ tetrabutyl ammonium hexafluorophosphate $\left(\mathrm{TBAPF}_{6}\right)$ as supporting electrolyte. The working electrode was the FTO glass slide and the saturated calomel electrode (SCE) and platinum foil were the reference electrode and auxiliary electrode, respectively. 


\section{Results and discussion}

\subsection{Absorption spectra}

Fig. 2 displays UV-Vis spectra and emission spectra of tdhab-ZnP in $\mathrm{CH}_{2} \mathrm{Cl}_{2}$ solution and on $\mathrm{TiO}_{2}$ film. The absorption spectrum of tdhab-ZnP in $\mathrm{CH}_{2} \mathrm{Cl}_{2}$ solution shows a series of visible bands between 400 and $650 \mathrm{~nm}$ due to $\pi-\pi^{*}$ absorptions of the conjugated macrocycle [15]. The tdhab-ZnP (Fig. 2a) exhibits an intense Soret absorption band at $427 \mathrm{~nm}$ and two low intensity Q-bands at 552 and $596 \mathrm{~nm}$, respectively. Light absorbing intensity of the Soret absorption band is above 20 times higher of that of Q-bands. Fig. 2b shows the absorption spectrum of tdhab-ZnP adsorbed on $\mathrm{TiO}_{2}$ nanoparticles. It is interesting to observe that the Soret band of tdhab-ZnP has not changed much for $\mathrm{NPs}^{\mathrm{TiO}_{2}}$ film, however, there is an increment of optical absorption in the broad 400 to $600 \mathrm{~nm}$ region. The absorption spectrum of the Q-band of tdhab-ZnP becomes broad and shifted to longer wavelength with an increase in absorbance for the Q-band absorbing at $567 \mathrm{~nm}$ and $614 \mathrm{~nm}$, respectively. The corresponding red shift of $\sim 15 \mathrm{~nm}$ and $\sim 18 \mathrm{~nm}$ as well as broadening of the Q-band of tdhab- $\mathrm{ZnP}$ on $\mathrm{TiO}_{2}$ NPs, comparing to that of tdhab-ZnP in $\mathrm{CH}_{2} \mathrm{Cl}_{2}$ solution, can be attributed to the formation of CT complex. It is clear to see that light absorbing intensity of Q-band increases much more comparing to porphyrin in $\mathrm{CH}_{2} \mathrm{Cl}_{2}$ solution, by above nearly 0.9 times of that of Soret absorption band.

As the tdhab-ZnP molecule binds through the phenol spacer in this case, there may be pure charge transfer (CT) transition due to phenol/ $/ \mathrm{TiO}_{2}$, as shown in Fig. 3. It was reported that $\mathrm{TiO}_{2}$ NPs can form a strong CT complex with dye molecules, such as alizarin [25], triphenylmethane dyes [26], and $\mathrm{Ru}-\mathrm{Cat}$ through the catechol spacer. It has already been discussed by Moser et al. [27] that $\mathrm{TiO}_{2}$ NPs can form a strong complex with catechols by formation of a five-membered ring. Similarly, in the present investigation tdhab-ZnP interacted strongly with $\mathrm{TiO}_{2}$ NPs by forming CT complex due to the interaction between phenol moiety and $\mathrm{TiO}_{2}$ NPs, which led to the red shift and the broadening of the $\mathrm{Q}$ bands for tdhab-ZnP on $\mathrm{TiO}_{2} \mathrm{NPs}$.

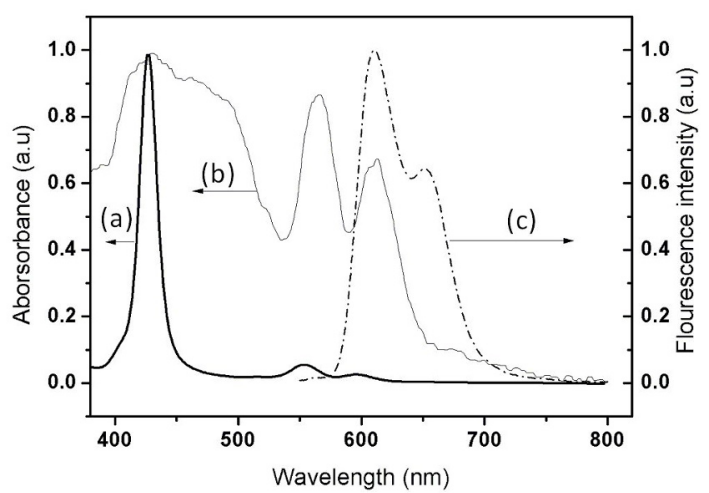

Fig. 2. Normalized absorption spectra of porphyrin: (a) tdhab-ZnP in $\mathrm{CH}_{2} \mathrm{Cl}_{2}$ solution (thick line); (b) tdhab-ZnP adsorbed onto a $\mathrm{TiO}_{2}$ film with the thickness of $6 \mu \mathrm{m}$ (thin line); (c) Emission spectrum of tdhab-ZnP in $\mathrm{CH}_{2} \mathrm{Cl}_{2}$ solution (dot), $\lambda_{\text {ex }}=429 \mathrm{~nm}$.

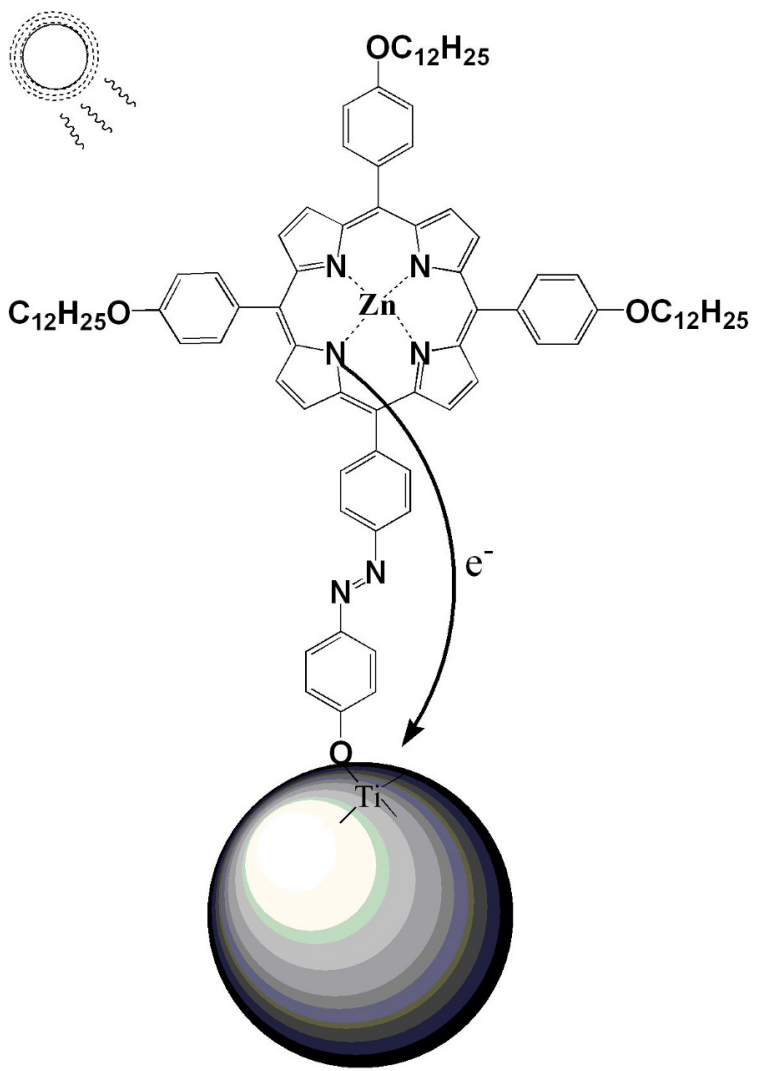

Fig. 3. Molecular structure of tdhab-ZnP and schematic illustration of the complexation reaction between the $\mathrm{TiO}_{2}$ surface and tdhab-ZnP through phenolic type binding. 


\subsection{Photovoltaic performance}

The current-voltage characteristics were measured using the $6 \mu \mathrm{m}$ thick $\mathrm{TiO}_{2}$ films modified with tdhab-ZnP and a Pt counter electrode under different light intensity irradiations. From Fig. 4 and Table 1, the short-circuit photocurrent density $\left(\mathrm{J}_{S c}\right)$, open-circuit photovoltage $\left(\mathrm{V}_{o c}\right)$ and fill factor (ff) of tdhab-ZnP sensitized solar cell with liquid electrolyte, measured under the $100 \mathrm{~mW} / \mathrm{cm}^{2}$ light intensity irradiation, are $14.1 \mathrm{~mA} / \mathrm{cm}^{2}, 0.521 \mathrm{~V}$ and 0.564 , respectively, yielding an overall conversion efficiency $(\eta)$ of $4.15 \%$, which gives the high photovoltaic performance. We can clearly see that the values of $\mathrm{J}_{s c}$ are directly proportional to the light intensity, but the values of $\eta$ enhance with the light intensity decreasing. The higher photoelectrical conversion efficiency at low light intensity can be ascribed to the higher fill factor (the value varies from 0.565 to 0.686 between 1 and 0.25 sun).

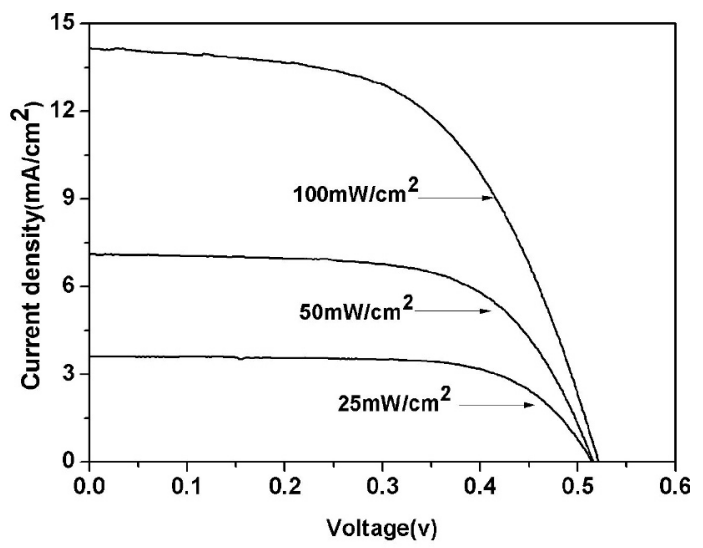

Fig. 4. Photocurrent-voltage plots of tdhab-ZnPsensitized solar cells measured in liquid electrolyte under illumination of different simulated solar light intensities. The cell active area was $0.2 \mathrm{~cm}^{2}$.

Table 1. Device performances of DSSCs with tdhab$\mathrm{ZnP}$ sensitized electrode and liquid electrolyte.

\begin{tabular}{ccccc}
\hline light intensity & $J_{s c}\left(\mathrm{~mA} / \mathrm{cm}^{2}\right)$ & $V_{o c}(\mathrm{~V})$ & $f f$ & $\eta$ \\
\hline \hline $100 \mathrm{~mW} / \mathrm{cm}^{2}$ & 14.1 & 0.521 & 0.565 & $4.15 \%$ \\
$50 \mathrm{~mW} / \mathrm{cm}^{2}$ & 7.05 & 0.515 & 0.643 & $4.67 \%$ \\
$25 \mathrm{~mW} / \mathrm{cm}^{2}$ & 3.61 & 0.514 & 0.686 & $5.09 \%$ \\
\hline
\end{tabular}

An action spectrum of IPCE for the tdhab-ZnPsensitized solar cell is depicted in Fig. 5. It is noteworthy that the tdhab-ZnP-sensitized cell reveals high IPCE values of up to $78 \%$ at around $430 \mathrm{~nm}$, extending the response of the photocurrent generation close to $800 \mathrm{~nm}$. The form of the action spectrum of IPCE is similar to that of the absorption spectrum of the tdhab-ZnP adsorbed onto $\mathrm{TiO}_{2}$ film, which indicates that the tdhab-ZnP displays the excellent photoelectric properties.

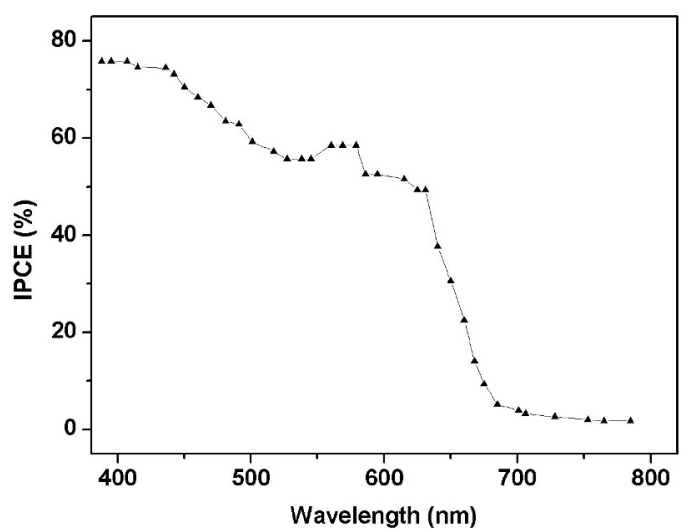

Fig. 5. Photocurrent action spectra of tdhab-ZnPsensitized solar cells measured with liquid electrolyte.

\subsection{Electrochemical properties}

Herein, we also discuss the energy level of highest occupied molecular orbital (HOMO) and lower unoccupied molecular orbital (LUMO) of tdhab$\mathrm{ZnP}$ molecule. From the intersection of the normalized absorption and emission spectra in $\mathrm{CH}_{2} \mathrm{Cl}_{2}$ solution (Fig. 2a and 2c), the zeroth-zeroth energy $\left(\mathrm{E}_{0-0}\right)$ is determined. The $\mathrm{E}_{0-0}$ value of tdhab-ZnP $(2.16 \mathrm{eV})$ implies the HOMO-LUMO gap of the $\pi$ elongated porphyrin. Cyclic voltammetry was used to determine the first oxidation potential of tdhab$\mathrm{ZnP}$. As the result of the cyclic voltammetry measurement (Fig. 6) the first oxidation potential of $\mathrm{ZnP}$ was determined as $0.82 \mathrm{~V}$ ( $v s$. SCE). The energy level of the porphyrin excited singlet state for tdhab-ZnP is $-1.34 \mathrm{~V}$ (vs. SCE) and it is higher than the $\mathrm{CB}$ of $\mathrm{TiO}_{2}(-0.74 \mathrm{~V}$ vs. SCE), $[3,29]$ whereas the energy level of the porphyrin radical cation for tdhab-ZnP $(0.82 \mathrm{~V}$ vs. SCE) is lower 
than those of the $\mathrm{I}^{-} / \mathrm{I}_{3}^{-}$couple $(0.26 \mathrm{~V}$ vs. SCE) (as shown in Fig. 7). Thus, charge separation from the tdhab-ZnP excited singlet state to the $\mathrm{CB}$ of $\mathrm{TiO}_{2}$ and charge shift from the $\mathrm{I}^{-} / \mathrm{I}_{3}^{-}$couple to the porphyrin radical cation are thermodynamically feasible.

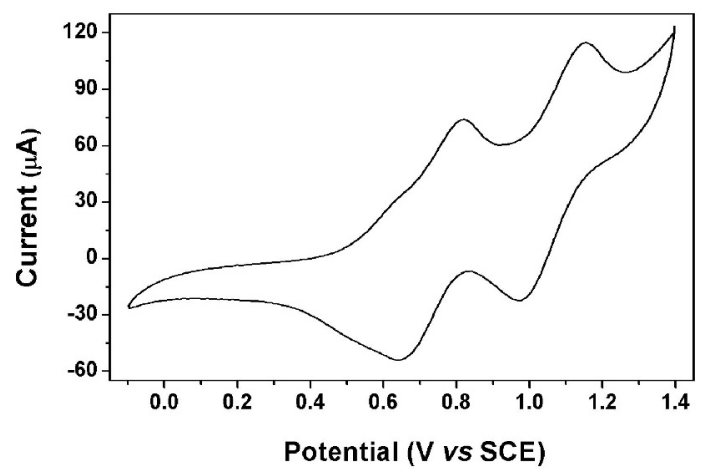

Fig. 6. Cyclic voltammograms of tdhab- $\mathrm{ZnP}$ in $\mathrm{CH}_{2} \mathrm{Cl}_{2}$ containing $0.1 \mathrm{M} \mathrm{TBAPF}_{6}$ as supporting electrolyte. Potentials $(\mathrm{V})$ are given versus SCE $(+0.24 \mathrm{~V}$ vs. NHE).

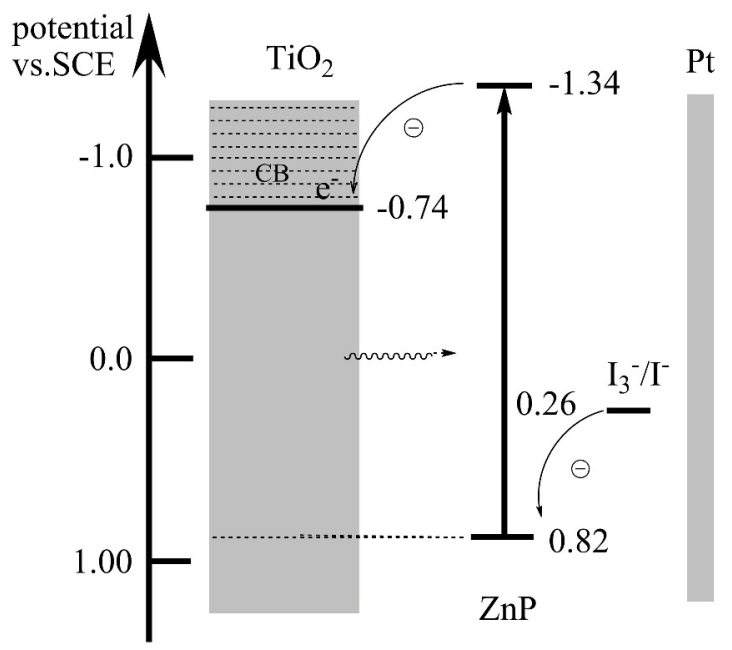

Fig. 7. Mechanistic scheme showing electronic excitation and transfer processes in the $\mathrm{ZnP}$-sensitized nanoparticles $\mathrm{TiO}_{2}$ solar cell.

\section{Conclusions}

We have successfully synthesized a novel $\pi$-elongated zinc porphyrin with benzenyl-azophenol. The zinc porphyrin has been adsorbed on nanoparticle $\mathrm{TiO}_{2}$ film by its phenolic group. UV-Vis absorption measurements have indicated that the tdhab-ZnP molecule forms a CT complex with $\mathrm{TiO}_{2}$ nanoparticals through the phenol moiety, which gives a broad absorption in the visible and NIR regions caused by an interfacial $\mathrm{CT}$ transition from the HOMO of tdhab-ZnP to the $\mathrm{TiO}_{2} \mathrm{CB}$. We constructed a novel photovoltaic cell based on the interfacial CT transition, with a power conversion efficiency of $4.15 \%$ and a high current density of $14.1 \mathrm{~mA} / \mathrm{cm}^{2}$ under AM 1.5 irradiation. These results clearly show that the elongation of a porphyrin $\pi$-system with benzenyl-azo-phenol is a useful tactic for collecting solar light in the visible and near infrared regions leading to improved cell performance of porphyrin sensitized solar cells. Further improvement of the power conversion efficiency in porphyrin-sensitized $\mathrm{TiO}_{2}$ cells will be possible by designing a porphyrin, in which a phenol moiety will be used as the bonding group of porphyrin.

\section{Acknowledgements}

We appreciate the financial support of the National Natural Science Foundation of China, the National Research Fund for Fundamental Key Projects (21273060), the HeiLongJiang Natural Science Fund (15008002-12111) and the HeiLongJiang Postdoctoral Science Fund (LBH-Z12218).

\section{References}

[1] Oregan B., Gratzel M., Nature, 353 (1991), 737.

[2] GRATZEL M., Inorg. Chem., 44 (2005), 6841.

[3] Kalyanasundaram K., Gratzel M., Coordin. Chem. Rev., 177 (1998), 347.

[4] Clifford J.N., Palomares E., Nazeeruddin M.K., Gratzel M., Nelson J., Li X., Long N.J., Durrant J.R., J. Am. Chem. Soc., 126 (2004), 5225.

[5] Nazeeruddin MD.K., PÉChy P., GRÄtZel M., Chem. Commun., 18 (1997), 1705.

[6] Shi C.N., Anson F.C., Inorg. Chem., 35 (1996), 7928.

[7] Campbell W.M., Burrell A.K., OfFicer D.L., Jolley K.W., Coordin. Chem. Rev., 248 (2004), 1363.

[8] Trachibana Y., Haque S.A., Mercer I.P., DurRAnt J.R., Klug D.R., J. Phys. Chem. B, 104 (2000), 1198.

[9] Montalti M., Wadhwa S., Kim W.Y., KipP R.A., SCHMEHL R.H., Inorg. Chem., 39 (2000), 76.

[10] Odobel F., Blart E., Lagree M., Villieras M., Boujtita H., El Murr N., Caramori S., BigNOZZI C.A., J. Mater. Chem., 13 (2003), 502.

[11] YAng X.J., Dai Z.F., MiURA A., TAMai N., Chem. Phys. Lett., 334 (2001), 257. 
[12] NAZEERUdDIN M.K., ZAKEERUDDIN S.M., HUMPhry-BAKER R., JiROUSEK M., LiSKA P., Vlachopoulos N., ShKlover V., Fischer C.H., GRATZEL M., Inorg. Chem., 38 (1999), 6298.

[13] Hara K., Dan-OH Y., Kasada C., Ohga Y., Shinpo A., Suga S., Sayama K., Arakawa H., Langmuir, 20 (2004), 4205.

[14] Ramakrishna G., Verma S., Jose D.A., Kumar D.K., Das A., Palit D.K., Ghosh H.N., J. Phys. Chem. B, 110 (2006), 9012.

[15] Nazeeruddin M.K., Humphry-Baker R., OFFICER D.L., CAMPBell W.M., BURREll A.K., GrATZEL M., Langmuir, 20 (2004), 6514.

[16] Schmidt-Mende L., Campbell W.M., Wang Q., Jolley K.W., OFFICER D.L., NAZEERUdDIN M.K., Gratzel M., ChemPhysChem, 6 (2005), 1253.

[17] Koumura N., Wang Z.S., Mori S., Miyashita M., Suzuki E., Hara K., J. Am. Chem. Soc., 128 (2006), 14256.

[18] Kroeze J.E., Hirata N., Koops S., Nazeeruddin M.K., SChMidt-Mende L., Gratzel M., DurRant J.R., J. Am. Chem. Soc., 128 (2006), 16376.

[19] Montanari I., Nelson J., Durrant J.R., J. Phys. Chem. B, 106 (2002), 12203.

[20] Bessho T., Zakeeruddin S.M., Yeh C.Y., Diau E.W.-G., GrÄtzel M., Angew. Chem. Int. Edit., 49 (2010), 6646.
[21] Yella A., Lee H.-W., Tsao H.N., Yi C., ChandiRAN A.K., NAZEERUdDIN M.K., DiaU E.W.-G., YEH C.-Y., ZAKEERUdDIN S.M., GRÄTZEL M., Science, 334 (2011), 629.

[22] Zhao Y., Zhai J., Tan S.X., Wang L.F., Jiang L., ZHU D.B., Nanotechnology, 17 (2006), 2090.

[23] Zhao Y., Chen W., Zhai J., Sheng X.L., He Q.G., Wei T.X., Bai F.L., Jiang L., Zhu D.B., Chem. Phys. Lett., 445 (2007), 259.

[24] Zaban A., Ferrere S., Sprague J., Gregg B.A., J. Phys. Chem. B, 101 (1997), 55.

[25] Ramakrishna G., Singh A.K., Palit D.K., Ghosh H.N., J. Phys. Chem. B, 108 (2004), 1701.

[26] Ramakrishna G., Ghosh H.N., Singh A.K., Palit D.K., Mittal J.P., J. Phys. Chem. B, 105 (2001), 12786.

[27] Moser J.E., Gratzel M., Chem. Phys., 176 (1993), 493.

[28] Rajh T., Chen L.X., Lukas K., Liu T., ThurNauer M.C., Tiede D.M., J. Phys. Chem. B, 106 (2002), 10543.

[29] Hagfeldt A., Gratzel M., Chem. Rev., 95 (1995), 49. 